\title{
Uji Fitokimia dan Aktivitas Antibakteri Ekstrak Etanol Daun Kencana Ungu (Ruellia tuberosa L.)
}

\author{
Santi Nur Handayani*1, Azizah Purwanti ${ }^{2}$, Windasari', Maulana Nur Ardian ${ }^{4}$ \\ 1,2,3Fakultas MIPA, Universitas Jenderal Soedirman \\ ${ }^{4}$ Fakultas Pertanian, Universitas Jenderal Soedirman \\ Jalan Prof. Dr. HR. Boenyamin, No. 708, Kel. Grendeng, Kec. Purwokerto Utara, Kab. \\ Banyumas, Jawa Tengah 53122 Indonesia \\ *E-mail: santinurhandayani@yahoo.com
}

\begin{abstract}
Abstrak
Kencana ungu (Ruellia tuberosa L.) merupakan tumbuhan dari dari genus Ruellia yang dapat dimanfaatkan sebagai antibakteri. Analisis kualitatif fitokimia dilakukan pada ekstrak etanol daun kencana ungu ( $R$. tuberosa L.). Tujuan penelitian adalah untuk mengetahui kandungan metabolit sekunder dan aktivitasnya sebagai antibakteri pada ekstrak daun kencana ungu. Metode yang digunakan adalah skrining fitokimia (kualitatif). Senyawa yang di uji dalam penelitian ini meliputi alkaloid, terpenoid, steroid, flavonoid, kardiakglikosida, saponin, dan tanin. Pengujian aktivitas antibakteri dilakukan pada ekstrak menggunakan pengamatan zona bening dengan metode difusi kertas cakram. Konsentrasi larutan ekstrak yang digunakan yaitu 500 ppm, 300 ppm, dan 200 ppm. Ekstrak etanol daun kencana ungu berdasarkan hasil penelitian diketahui mengandung senyawa alkaloid, steroid, flavonoid, saponin, dan tanin. Larutan dengan konsentrasi 500 ppm menunjukkan diameter zona bening terbesar pada kedua bakteri. Hasil dari penelitian ini menyimpulkan bahwa ekstrak etanol daun kencana ungu berpotensi sebagai antibakteri.
\end{abstract}

Kata kunci: Daun kencana ungu; fitokimia; metabolit sekunder; antibakteri

\begin{abstract}
Kencana Ungu (Ruellia tuberosa L.) is a plant from the genus Ruellia that can be used as antibacterial. Qualitative phytochemistry analysis has been done towards ethanol extract of kencana ungu leaves $(R$ tuberosa L.). This study aims to investigate secondary metabolic compounds and antibacterial activity of kencana ungu leaves extract. The method used was the phytochemistry analysis (qualitative). The chemicals tested were terpenoids, flavonoids, alkaloids, steroids, cardiac glycoside, tannins, and sapponins. Furthermore, the antibacterial activity of the extract was tested using a disc paper diffusion method to observe the diameter of the formed clear zone in every treatment. The concentration of extract solutions used was $500 \mathrm{ppm}, 300 \mathrm{ppm}$, and $200 \mathrm{ppm}$. The result showed that kencana ungu leaves extract contains alkaloids, steroids, flavonoids, saponins, and tannins. A solution with 500 ppm concentration showed the largest diameter of the clear zone. From these comes about, can be concluded that kencana ungu leaves extract is potential as antibacterial.
\end{abstract}

Keywords: Kencana ungu leaves; phytochemistry; secondary metabolites; antibacterial

\section{Pendahuluan}

Indonesia adalah negara ketiga yang memiliki hutan hujan tropis terbesar setelah negara Brazil dan Zaire. Hal ini membuat
Indonesia kaya akan keanekaragaman hayati yang berpotensi sebagai tanaman obat diantaranya sebagai antibakteri. Aktivitas antibakteri suatu tanaman disebabkan oleh senyawa metabolit sekunder yang terkandung 
di dalamnya. Makhluk hidup memperoleh senyawa metabolit sekunder dari bahan organik (protein, lemak, karbohidrat) yang mengalami reaksi sekunder. Senyawa ini berfungsi sebagai pertahanan tanaman terhadap kondisi lingkungannya. Metabolisme sekunder terdiri dari sejumlah senyawa khusus (kurang lebih 2000 jenis senyawa). Senyawa ini dikelompokkan menjadi beberapa kelompok yaitu golongan fenolik, alkaloid, terpeniod, dan poliketida (Julianto, 2019). Senyawa metabolit sekunder dihasilkan oleh banyak tanaman, salah satunya yaitu daun kencana ungu (Ruellia tuberosa L.).

Kencana ungu (R. tuberosa L.) atau pletekan dalam bahasa daerah merupakan tumbuhan dari genus Ruellia, berasal dari Amerika Tropis dan ternaturalisasi di Asia Tenggara, salah satunya di Indonesia (Manikandan \& Doss, 2010). Tumbuhan kencana ungu di Indonesia, terutama di Pulau Jawa tumbuh sebagai tanaman liar yang tumbuh subur pada ketinggian mulai dari 150 $\mathrm{m}$ di atas permukaan laut. Tangkai daunnya memiliki panjang $2 \mathrm{~cm}$. Bunganya berwarna ungu mencolok dengan panjang 5-5,5 cm. Tumbuhan ini biasanya ditemukan di tempat lembab dan teduh dengan masa pertumbuhan yang cepat, sehingga mudah dibudidayakan (Lemmens \& Bunyapraphatsara, 2003).

Senyawa metabolit sekunder seperti alkaloid, flavonoid, triterpenoid, steroid, dan saponin terkandung dalam tanaman kencana ungu (Vitalia, et al., 2016). Menurut Safitri et al. (2020), ekstrak tumbuhan daun kencana ungu memiliki aktivitas antidiabetik. Selain itu, ekstraknya juga berpotensi sebagai inhibitor enzim $\alpha$-amilase pada penderita diabetes. Senyawa metabolit sekunder pada daun kencana ungu menunjukkan aktivitas antijamur Candida albicans (Mutammima, 2017). Potensi senyawa metabolit sekunder daun kencana ungu sebagai antidiabetik dan antijamur menjadi dasar dilakukannya uji untuk mengetahui aktivitas antibakteri pada daun kencana ungu. Tujuan penelitian ini adalah untuk mengetahui kandungan senyawa metabolit sekunder daun kencana ungu yang diambil dari wilayah Purwokerto, Kabupaten Banyumas, Jawa Tengah. Selanjutnya dilakukan analisis aktivitas antibakteri ekstrak daun kencana ungu pada bakteri Staphylococcus aureus dan Escherichia coli.

\section{Metode Penelitian}

\section{Alat dan Bahan}

Alat yang digunakan meliputi wadah plastik, oven, blender, labu ukur, penggaris, erlenmeyer, batang pengaduk, timbangan analitik, cotton bud steril, jarum ose, cawan petri, tabung reaksi, rak tabung reaksi, waterbath, pipet tetes, pipet ukur, dan pipet mikro. laminar air flow, bunsen, dan autoclave. Bahan yang digunakan terdiri dari daun tumbuhan kencana ungu ( $R$. tuberosa L.), ammonia encer, asam asetat anhidrida, alumunium klorida $1 \%$, asam sulfat pekat, ammonium hidroksida pekat, asam asetat glasial, besi (III) klorida 0,1\%, asam klorida $1 \%$, butanol $0,1 \mathrm{M}$, kalium heksasianoferat (III) 0,008 M, kloroform, fenol, standar tanin, minyak zaitun, pereaksi Meyer \& Wegner, akuades, NaTPP, Nutrient broth (NB) (Merck), dan etanol 70\%. Uji antibakteri menggunakan medium NA (Nutrient agar) (Merck), isolat bakteri $E$. coli dan $S$. aureus.

\section{Pembuatan Ekstrak}

Pembuatan ekstrak daun tumbuhan kencana ungu dilakukan dengan metode maserasi, yaitu dengan mencuci daun, kemudian dikering-anginkan sampai kering patah, kemudian dihaluskan sampai menjadi serbuk halus. Sebanyak $1 \mathrm{~kg}$ serbuk daun kencana ungu diekstraksi dengan etanol 96\% selama 24 jam. Ekstraksi diulangi sebanyak 2 kali. Selanjutnya, filtrat hasil ekstraksi dipekatkan menggunakan rotary evaporator sampai berbentuk pasta.

\section{Uji Kualitatif Fitokimia}

Uji fitokimia meliputi uji flavonoiod, tanin, glikosida, saponin, kardiakglikosida, terpenoid, dan alkaloid secara kualitatif.

\section{Uji flavonoid}

\section{Flavonoid 1}

Dua gram ekstrak disiapkan dalam gelas beaker dan ditambah $20 \mathrm{~mL}$ akuades, didihkan dan disaring. 0,5 mL filtrate ditambahkan $5 \mathrm{~mL}$ ammonia encer dan $5 \mathrm{~mL}$ asam sulfat pekat. Diamati reaksinya.

Flavonoid 2

Dua gram ekstrak disiapkan dalam gelas beaker dan ditambah $20 \mathrm{ml}$. akuades, kemudian di didihkan dan disaring. 0,5 ml filtrat ditambahkan 5 tetes aluminium klorida $1 \%$. Diamati reaksinya. 


\section{Uji terpenoid}

Disiapkan $2 \mathrm{~mL}$ ekstrak ditambahkan dengan asam klorida pekat 3 tetes dan asam sulfat pekat sebanyak 1 tetes. Diamati reaksi yang terjadi.

\section{Uji steroid}

Disiapkan $2 \mathrm{~mL}$ ekstrak ditambahkan dengan asam klorida pekat sebanyak 3 tetes dan asam sulfat pekat sebanyak 1 tetes. Diamati reaksi yang terjadi.

\section{Uji tanin}

Disiapkan $2 \mathrm{~mL}$ ekstrak dipanaskan menggunakan hot plates 5 menit kemudian ditambahkan beberapa tetes $\mathrm{F}_{\mathrm{e}} \mathrm{Cl}_{3} 1 \%$. Reaksi yang terjadi diamati.

\section{Uji saponin}

Dua gram ekstrak ditambah akuades sebanyak $20 \mathrm{~mL}$ kemudian dididihkan dan disaring. Filrat sebanyak $10 \mathrm{~mL}$ ditambahkan $5 \mathrm{~mL}$ akuades kemudian dikocok kuat hingga terbentuk busa. Busa yang terbentuk ditambahkan 3 tetes minyak zaitun dan dikocok kembali. Diamati reaksi yang terjadi.

\section{Uji kardiakglikosida}

Sebanyak 2 gram ekstrak ditambah 10 mL methanol. Larutan dididihkan dan disaring untu mendapat filtratnya. Kemudian ditambah asam asetat glasial yang mengandung 1 tetes $\mathrm{FeCl}_{3} 1 \%$. Selanjutnya ditambah asam sulfat pekat. Diamati reaksi yang terjadi.

\section{Uji alkaloid}

Disiapkan 3 gram ekstrak dilarutkan dalam $0,05 \mathrm{~N}$ amonia klorofom sebanyak 10 mL. Larutan dikocok lalu disaring untuk mendapatkan filtratnya. Filtrat yang dihasilkan ditambah $5 \mathrm{~mL}$ asam sulfat dan dikocok lalu didiamkan sampai terbentuk 2 lapisan. Lapisan atas kemudian diuji menggunakan pereaksi Meyer dan Wegner. Reaksi yang terjadi diamati.

\section{Uji Aktivitas Antibakteri}

Larutan uji disiapkan dengan melarutkan ekstrak daun kencana ungu pada akuades, ditambahkan pengemulsi tween 80 supaya ekstrak terlarut sempurna. Dibuat seri konsentrasi larutan uji 500 ppm, 300 ppm, dan $300 \mathrm{ppm}$. Setiap perlakuan dari konsentrasi larutan ekstrak daun kencana ungu dilakukan uji pada bakteri $E$. coli dan $S$. aureus dengan metode difusi kertas cakram. Isolat bakteri uji ditumbuhkan dalam medium NB (Nutrient Broth) dan dinkubasi selama $1 \mathrm{x}$ 24 jam. Bakteri uji pada medium NB dioleskan pada medium NA (Nutrient Agar) yang telah padat pada cawan petri menggunakan metode swab dengan cotton bud steril. Sebanyak 1 tetes larutan uji diteteskan pada kertas cakram steril, kemudian kertas cakram diletakkan pada medium NA yang sudah ditumbuhkan bakteri uji. Diameter zona bening diukur untuk mengetahui daya antibakteri.

\section{Hasil dan Pembahasan}

\section{Uji Kualitatif Fitokimia Ekstrak Daun Kencana Ungu}

Ekstrak etanol daun kencana ungu yang didapat dari hasil maserasi yaitu sebanyak 43,6 gram. Uji kualitatif fitokimia ekstrak daun kencana ungu dilakukan menggunakan pereaksi warna. Uji fitokimia dilakukan untuk melihat senyawa metabolit sekunder apa saja yang terkandung dalam ekstak daun kencana ungu. Pereaksi yang digunakan bersifat polar sehingga mampu melarutkan sampel dengan prinsip like dissolve like. Hasil yang didapat seperti tertera pada Tabel 1.

Tabel 1. Hasil Uji Fitokimia.

$\begin{array}{lcc}\begin{array}{l}\text { Metabolit } \\ \text { Sekunder }\end{array} & \text { Pereaksi } & \begin{array}{c}\text { Hasil } \\ \text { Pengujian }\end{array}\end{array}$

\begin{tabular}{llc}
\hline Saponin & Minyak & ++ \\
& zaitun & ++ \\
Tanin & $\mathrm{FeCl}_{3}$ & ++ \\
Flavonoid & $\mathrm{NH}_{3} ; \mathrm{H}_{2} \mathrm{SO}_{4}$ & +++ \\
Terpenoid & $\mathrm{HCl}_{2} \mathrm{H}_{2} \mathrm{SO}_{4}$ & - \\
Kardiakglikosida & $\mathrm{FeCl}_{3}$ & - \\
& $; \mathrm{H}_{2} \mathrm{SO}_{4}$ & \\
Alkaloid & Meyer & + \\
Alkaloid & Wegner & ++ \\
Steroid & $\mathrm{HCl} ; \mathrm{H}_{2} \mathrm{SO}_{4}$ & + \\
\hline
\end{tabular}

Keterangan: $(+++)=$ banyak, $(++)=$ sedang, $(+)=$ kurang, $(-)=$ tidak ada.

Tabel 1. menunjukkkan bahwa ekstrak daun kencana ungu mengandung senyawa metabolit sekunder berupa saponin, tanin, flavonoid, alkaloid, dan dan steroid. Pada pengujian alkaloid pereaksi yang digunakan yaitu Mayer dan Wegner yang apabila terjadi endapan putih pada pereaksi Mayer dan endapan coklat pada pereaksi Wegner maka 
hasilnya positif. Prinsip dasar metode analisis ini yaitu reaksi pengendapan yang terjadi karena adanya penggantian ligan (Svehla, 1985). Sedangkan pada pengujian flavoboid, baik flavonoid 1 , dan 2 terbentuk warna kekuningan pada larutan uji setelah berekasi dengan reagen. Flavonoid merupakan jenis senyawa fenol yang berubah warna ketika bereaksi dengan basa dikarenakan adanya gugus aromatik yang terkonjugasi(Markham, 1988).

Uji positif adanya saponin ditandai dengan terbentuknya emulsi. Penambahan minyak zaitun berfungsi sebagai sumber kolesterol dalam memurnikan saponin. Hal ini menyebabkan terbentuknya senyawa kompleks adisi yang tidak larut dalam air (Robinson, 1995). Sedangkan pada uji tanin, perubahan warna menjadi warna hijau tua akibat reaksi reduksi besi (III) menjadi besi (II) oleh tanin yang merupakan kelompok senyawa polifenol menunjukkan hasil yang positif. Sama halnya dengan uji tanin, hasil positif dari uji steroid ditandai dengan terbentuknya warna hijau-biru pada larutan. Reaksi yang terjadi yaitu reaksi LiebermannBuchard yang menjelaskan bahwa apabila steroid direaksikan dengan asam sulfat pekat dan asam asetat anhidrat akan menghasilkan warna hijau atau biru (Robinson, 1995).

Data uji fitokimia menunjukkan hasil bahwa ekstrak daun kencana ungu berpotensi sebagai antibakteri. Senyawa metabolit sekunder dalam menghambat pertumbuhan bakteri pada umumnya yaitu dengan cara mendenaturasi protein sel, dan merusak permeabilitas membran sel bakteri (Bobbarala, 2012).

\section{Uji Aktivitas Antibakteri}

Pengujian efektivitas secara in vitro dilakukan dengan metode difusi kertas cakram. Efektivitas antibakteri ditunjukkan dengan adanya zona bening di sekitar cakram yang sudah mengandung larutan ekstrak daun kencana ungu yang diuji. Zona bening terbentuk karena adanya senyawa antibakteri yang berdifusi ke dalam lapisan agar dan menghambat pertumbuhan dari bakteri uji, sedangkan untuk lapisan agar yang ditumbuhi bakteri uji akan terlihat keruh.

Hasil pengujian aktivitas antibakteri yang dilakukan pada bakteri $E$. coli dan $S$. aureus berdasarkan diameter zona hambat dapat dilihat pada Tabel 2. Uji efektivitas antimikroba dilakukan untuk melihat kemampuan larutan uji dalam menghambat bakteri $E$. coli dan $S$. aureus.

Tabel 2. Hasil Uji Antibakteri.

\begin{tabular}{lll}
\hline Bakteri Uji & Konsentrasi & $\begin{array}{l}\text { Zona } \\
\text { Bening }\end{array}$ \\
\hline & Kontrol positif & $30 \mathrm{~mm}$ \\
& Kontrol negatif & $0 \mathrm{~mm}$ \\
$\begin{array}{l}\text { Staphylococcus } \\
\text { aureus }\end{array}$ & $500 \mathrm{ppm}$ & $4 \mathrm{~mm}$ \\
& $300 \mathrm{ppm}$ & $2 \mathrm{~mm}$ \\
& 200 ppm & $2 \mathrm{~mm}$ \\
\hline & Kontrol positif & $30 \mathrm{~mm}$ \\
& Kontrol negatif & $0 \mathrm{~mm}$ \\
& 500 ppm & $2 \mathrm{~mm}$ \\
& 300 ppm & $1,5 \mathrm{~mm}$ \\
& 200 ppm & $1 \mathrm{~mm}$
\end{tabular}

Keterangan: Diameter cakram $6 \mathrm{~mm}$.

Hasil uji menunjukkan bahwa pada konsentrasi 500 ppm larutan uji memiliki nilai diameter zona hambat lebih besar dibandingkan konsentrasi 300 ppm dan 200 ppm. Hal tersebut disebabkan karena konsentrasi 500 ppm mengandung ekstrak yang lebih pekat sehingga aktivitasnya lebih besar. Senyawa metabolit sekunder yang terkandung dalam daun kencana ungu akan mengganggu permeabilitas sel bakteri, menghambat pembentukan dinding sel, serta menghambat kerja enzim dan sintesis protein pada sel bakteri. Kontrol negatif yang digunakan dalam uji ini yaitu pelarut akuades. Pengujian kontrol negatif dilakukan untuk memastikan bahwa pelarut yang digunakan tidak memiliki aktivitas antibakteri dan aktivitas antibakteri didapatkan karena adanya ekstrak daun kencana ungu. Kontrol positif yang digunakan adalah antibiotik yang telah beredar di pasaran (tetrasiklin). Pengujian kontrol positif dilakukan untuk membandingkan nilai efektivitas aktivitas antibakteri larutan uji dengan antibiotik yang beredar. Terbentuknya zona bening pada setiap perlakuan menunjukkan bahwa ekstrak daun kencana ungu mampu menghambat atau mengurangi pertumbuhan bakteri patogen seperti $S$. aureus dan E. coli. Diameter zona bening yang terbentuk pada bakteri $S$. aureus lebih besar dibandingkan dengan bakteri $E$. 
coli. Hal ini disebabkan adanya perbedaan sensitivitas bakteri gram positif dan gram negatif terhadap aktivitas antibakteri. $S$. aureus sebagai bakteri gram positif memiliki struktur dinding sel yang lebih sederhana dibandingkan dengan $E$. coli yang merupakan bakteri gram negatif, sehingga antibakteri lebih mudah masuk ke dalam sel bakteri $S$. aureus (Yunita, 2012). Struktur dinding sel bakteri gram negatif lebih kompleks karena adanya lapisan peptidoglikan pada membran luar sel yang berperan sebagai barier (Saputra, et al., 2019).

\section{Simpulan}

Berdasarkan hasil penelitian dapat disimpulkan bahwa esktrak etanol daun kencana ungu mengandung senyawa metabolit sekunder berupa saponin, tanin, flavonoid, alkaloid, dan dan steroid. Uji aktivitas antibakteri menunjukkan bahwa ekstrak etanol daun kencana ungu dengan konsentrasi 500 ppm memiliki zona bening sebesar $4 \mathrm{~mm}$ pada Staphylococcus aureus dan $2 \mathrm{~mm}$ pada Escherichia coli.

\section{Ucapan Terima Kasih}

Ucapan terima kasih diucapkan kepada Dirjen DIKTI yang telah memberikan dana penelitian PKM P. Terima kasih kepada Laboratorium Kimia Organik Fakultas MIPA serta Laboratorium Agronomi dan Hortikultura Fakultas Pertanian, Universitas Jenderal Soedirman. Terima kasih pula kepada pimpinan beserta jajaran dosen Universitas Jenderal Soedirman yang telah memberikan saran dan dukungan selama proses penelitian.

\section{Daftar Pustaka}

Bobbarala, V., 2012, Antimicrobial Agent. Croatia: Intech.

Julianto, T. S., 2019, Fitokimia Tinjauan Metabolit Sekunder dan Skrining Fitokimia, Universitas Islam Indonesia: Yogyakarta.

Lemmens, R. H. M. J. dan Bunyapraphatsara, N. 2003. Plant Resources of SouthEast Asia 12(3) Medical and Poisonou s Plant, Journal of Ethnopharmacology, 87(1), 119-129.

Manikandan A. dan Doss, DVA., 2010, Evaluation of biochemical content, nutritional value, trace elements, SDSPAGE and HPTLC profiling in the leaves of Ruellia tuberosa L. and Dipteracanthus patulus Jacq, J Chem Pharm Res, 2 (1), 295-303.

Markham, K.R., 1988, Cara Mengidentifikasi Flavonoid. Bandung: ITB.

Mutammima, N., 2017, Uji Aktivitas Antijamur, Penentuan Konsentrasi Hambat Minimum (KHM) Dan Konsentrasi Bunuh Minimum (KBM) Serta KLT-Bioautografi Ekstrak Etanol Daun Plethekan (Ruellia tuberosa L.) terhadap Candida albicans, Skripsi, Universitas Islam Negeri Maulana Malik Ibrahim Malang.

Robinson, T. 1995. Kandungan Organik Tumbuhan Tinggi. Bandung: ITB.

Safitri, A., Fatchiyah., Dewi R.T., Anna R. 2020. Phytochemical screening, in vitro antioxidant activity, and in silico antidiabetic activity of aqueous extracts of Ruellia tuberosa L. Journal of Applied Pharmaceutical Science, 10(3), 101108.

Saputra, A., Baru S., dan Idin, S. 2019. Karakterisasi Senyawa Metabolit Sekunder dan Uji Anti Bakteri Spons Phyllospongia Sp. di Perairan yang Berbeda, Sapa Laut, 4(4), 153-162.

Shevla, G., 1985, Buku Teks Analisis Anorganik Kualitatif Makro dan Semi Mikro. Jakarta: PT. Kalman Media Pustaka.

Vitalia, N., Ahmad N., Aktsar R. A., 2016, Uji Toksisitas Ekstrak Daun Pletekan (Ruellia tuberosa L.) dengan metode Brine Shrimp Lethality Test (BSLT), Jurnal Fitofarmaka Indonesia, 3 (1), 124-129.

Yunita, D.W. 2012, Aktivitas Antibakteri E kstrak Etanol Kayu Secang (Caesalpinia sappan L.) terhadap Bakteri Staphylococcus aureus, Sigella sonnei, dan Escherichia coli, Skripsi, Universitas Muhammadiyah Surakarta. 